\title{
TLR4 wt Allele
}

National Cancer Institute

\section{Source}

National Cancer Institute. TLR4 wt Allele. NCI Thesaurus. Code C52241.

Human TLR4 wild-type allele is located within 9q32-q33 and is approximately $11 \mathrm{~kb}$ in length. This allele, which encodes toll-like receptor 4 protein, is involved in pathogen recognition, signal transduction and innate immunity. Mutations in the gene are associated with differences in LPS responsiveness. 